\title{
Application of bioelectrical impedance analysis to assess rabbit's body composition from 25 to 77 days of age
}

\author{
A. Saiz, A. I. Garcia-Ruiz, J. Fuentes-Pila, and N. Nicodemus
}

\begin{abstract}
The aim of the study was to develop prediction equations for assessing, in vivo, the whole body composition of growing rabbits. The accuracy of the models obtained was externally validated with independent data sets. One hundred fifty rabbits grouped at 5 different ages $(25,35,49,63$, and $77 \mathrm{~d})$ were used. A body composition analyzer with 4 terminals was used to obtain resistance $(\mathrm{Rs} ; \Omega)$ and reactance $(\mathrm{Xc} ; \Omega$ ) values. The distance between internal electrodes $(\mathrm{D} ; \mathrm{cm})$, body length (Len; $\mathrm{cm})$, and live $\mathrm{BW}(\mathrm{g})$ were also registered. Average values of Rs, Xc, impedance $(\mathrm{Z})$, Len, $\mathrm{D}$, and $\mathrm{BW}$ were $83.5 \pm 23.1 \Omega$, $18.2 \pm 3.8 \Omega, 85.6 \pm 22.9 \Omega, 30.6 \pm 6.9 \mathrm{~cm}, 10.8 \pm 3.1$ $\mathrm{cm}$, and $1,454 \pm 845 \mathrm{~g}$, respectively. At each selected age, animals were slaughtered, ground, and frozen $\left(-20^{\circ} \mathrm{C}\right)$ for determining water, fat, $\mathrm{CP}$, ash, and $\mathrm{GE}$ $(70.5 \pm 3.36 \%, 27.7 \pm 7.61 \% \mathrm{DM}, 54.9 \pm 5.41 \% \mathrm{DM}$, $11.1 \pm 1.55 \% \mathrm{DM}$, and $2,267 \pm 183 \mathrm{~kJ} / 100 \mathrm{~g} \mathrm{DM}$, on average, respectively). Fat and GE contents increased
\end{abstract}

with the age, whereas $\mathrm{CP}$, ash, and water contents decreased. A multiple linear regression analysis was used to determine the prediction equations, using BW, Len, and $Z$ data as independent variables. Equations obtained to estimate water (g), CP (g), fat (g), ash (g), and GE (MJ) had coefficient of determination $\left(R^{2}\right)$ values of $0.99,0.99,0.97,0.98$, and 0.99 , respectively, and the relative mean prediction error (RMPE) was $2.79,6.15,24.3,15.2$, and $10.6 \%$, respectively. When water was expressed as a percentage, the $R^{2}$ and RMPE were 0.85 and $2.30 \%$, respectively. When prediction of the content of protein ( $\% \mathrm{DM})$, fat ( $\% \mathrm{DM})$, ash (\% DM), and energy ( $\mathrm{kJ} / 100 \mathrm{~g} \mathrm{DM})$ was done, values of $0.79,0.83,0.71$, and 0.86 , respectively, for $R^{2}$ and $5.04,18.9,12.0$, and $3.19 \%$, respectively, for RMPE were obtained. It could be concluded that bioelectrical impedance analysis is a good, noninvasive method to estimate, in vivo, whole body composition of growing rabbits from 25 to $77 \mathrm{~d}$ of age

\section{INTRODUCTION}

Rabbit meat is usually considered a lean meat, characterized by a lower fat (on average, $4.6 \mathrm{~g} / 100 \mathrm{~g}$ fresh meat) and energy content (on average, $133 \mathrm{kcal} / 100 \mathrm{~g}$ fresh meat) compared with red meats. However, rabbit composition and nutrient retention is variable, leading to the necessity of their assessment, both for research and commercial purposes (farms, industry, and slaughterhouses). In recent years, the rabbit meat industry has become interested in introducing rabbit meat as an ingredient in processed food products adapted to modern consumer demands (Petracci and Cavani, 2013). In this sense, it is important to get more knowledge about rabbit meat characteristics. Different authors (Fraga et al., 1978; Szendrö et al., 1998; Milisits et al., 2003) have studied the evolution of rabbits' body composition with age. In most of these studies, the comparative slaughter method was used. However, this method is expensive and does not allow researchers to follow the 
evolution of the body composition on the same animal. The in vivo determination of body composition during the growing period would allow researchers to study variations in body composition without killing animals Many other methods, such as dilution with deuterium oxide (Fekete and Brown., 1992), magnetic resonance imaging (Szendrö et al., 1992; Köver et al., 1996, 1998), and the total body electrical conductivity (TOBEC) method (Milisits et al., 1999; Fortun-Lamothe et al., 2002) have been also used in growing rabbit and rabbit breeding does. However, these methods are expensive and their application is not easy. In other species (swine, lambs, and beef), an alternative in vivo technique, the bioelectrical impedance analysis (BIA) method, which is based in the resistivity of the body when an alternating electrical current is introduced in the animal, has been successfully applied (Swantek et al., 1992, 1999; Berg and Marchello, 1994; Daza et al., 2006). Talma et al. (2013) reviewed several studies about the use of this method in humans and suggested that BIA is a practical method to estimate body fat in children and adolescents but that its validity and measurement error are not satisfactory. In rabbits, Nicodemus et al. (2009) and Pereda (2010) observed that this technique could be a relatively cheap, practical, easy, and quick method to predict body composition of does. The aim of this study was to develop prediction equations for assessing, in vivo, the whole body composition of growing rabbits from the parameters measured by the BIA technique.

\section{MATERIAL AND METHODS}

This study was approved by the Ethics Committee of the Trouw Nutrition R\&D Poultry Research Centre (Casarrubios del Monte, Spain). Rabbits were handled according to the principles for the care of animals in experimentation (Spanish Royal Decree 53/2013; Government of Spain, 2013)

\section{Animal and Housing}

This study was performed at the Trouw Nutrition R\&D Poultry Research Centre in Casarrubios Del Monte (Toledo, Spain), in collaboration with the Technical University of Madrid (Universidad Politécnica de Madrid; Madrid, Spain). Two hundred New Zealand $\times$ Californian rabbits were selected at random and blocked by litter ( 150 animals for the calibration group and 50 for the external validation group). Animals were allocated with lactating does in polyvalent cages measuring 380 by 1,000 by $320 \mathrm{~mm}$ until weaning ( 25 or $35 \mathrm{~d}$, depending of the slaughter age). Then, animals were randomly, individually housed in flat-deck cages measuring 250 by 440 by $300 \mathrm{~mm}$. Rabbits were kept

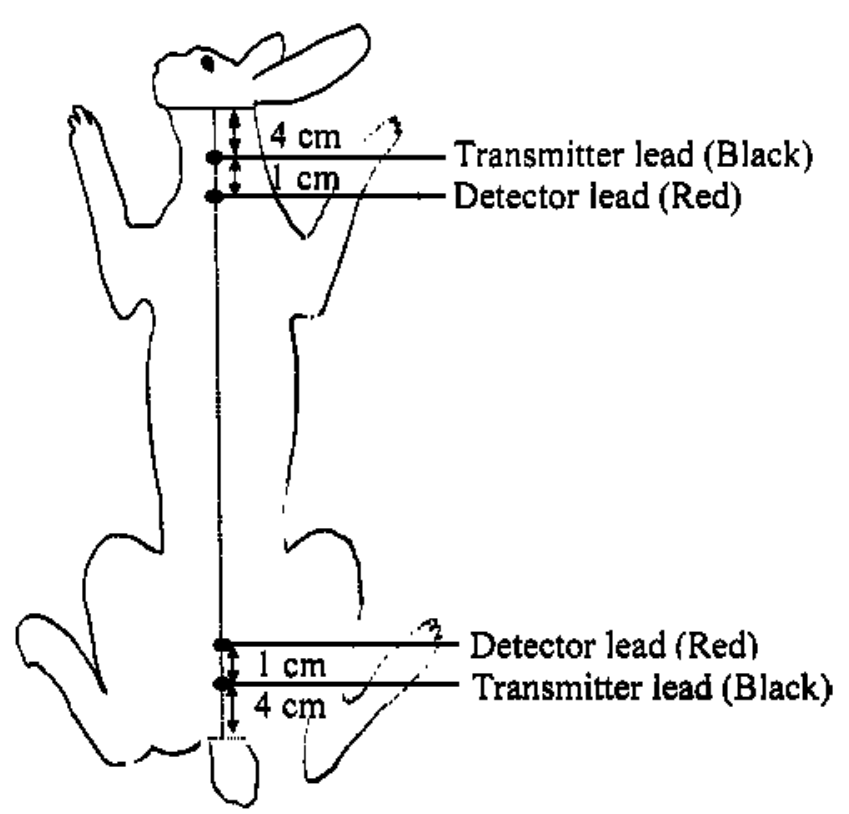

Figure 1. Location of electrodes applied by subcutaneous needle placement in the live rabbit body.

under controlled environmental conditions (room temperature between 16 and $24^{\circ} \mathrm{C}$, with a light dark cycle of $16: 8 \mathrm{~h}$; the light was switched on at $0730 \mathrm{~h}$ ).

\section{Diets}

The composition of diets is shown in Table 1 Animals were fed a commercial diet for unweaned rabbits, Cunilactal Super (NANTA, Griñon, Spain), until weaning at $35 \mathrm{~d}$ and a standard growing rabbit diet from $35 \mathrm{~d}$ to slaughter. Both feeds were formulated to meet animal requirements according to de Blas and Mateos (2010). Feed and water were supplied ad libitum during the whole trial. Animals were not supplied with any antibiotic during the growing period.

\section{Bioelectrical Impedance Analysis Measurements}

Bioelectrical impedance analysis was performed at 5 different ages (suckling rabbits at 25 and $35 \mathrm{~d}$ and growing rabbits at 49,63 , and $77 \mathrm{~d}$ of age) to cover the common rabbit growing period between usual weaning and slaughtering ages in commercial rabbit livestock. At $1100 \mathrm{~h}$, the BW and feed intake of animals were registered and a body composition analyzer with 4 terminals (model BIA-101; RJL Systems Inc., Detroit, MI) was used to register resistance (Rs; $\Omega$ ) and reactance (Xc; $\Omega)$ values. Animals were placed on a nonslip and plain surface (wood or polystyrene) located above the cages to allow animals to be quiet and calm. Then, each pair of electrodes ( 1 black and 1 red) were subcutaneously inserted with a disposable needle (21 gauge $\times 1.5^{\prime \prime}[0.8$ by $40 \mathrm{~mm}]$ ), at $4 \mathrm{~cm}$ from the base of the ears and at $4 \mathrm{~cm}$ 
from the base of the tail, respectively, as shown in Fig. I In each animal, BIA measurement was performed twice (once every half hour) between 11 and $13 \mathrm{~h}$ to determine repeatability. The distance between internal electrodes (D; red ones) and the body length (Len) of the animals were measured. The impedance $(Z)$ value was calculated as $\mathrm{Z}=\left(\mathrm{Rs}^{2}+\mathrm{Xc}^{2}\right)^{1 / 2}$. The volumes (voll and vol 2$)$ of the animals were calculated as voll $=\mathrm{D}^{2} / \mathrm{Rs}$ and vol $2=$ $\mathrm{D}^{2} / \mathrm{Z}$ to determine the relation between $\mathrm{Z}$ and volume that was fomulated by Lukaski et al. (1985).

\section{Body Composition Measurement}

Thirty animals per age $(25,35,49,63$, and $77 \mathrm{~d})$ were randomly selected to be included in the calibration body composition group (CG). After the BIA measurements were performed, rabbits were euthanized in $\mathrm{a} \mathrm{CO}_{2}$ atmosphere. Slaughtered animals were stored at $-20^{\circ} \mathrm{C}$ until chemical analyses. Before carrying out chemical analyses, whole animals, including the fur, skin, bones, organs, and digestive contents, were slowly thawed during $24 \mathrm{~h}$ and ground with an industrial blade chopper (C-15 EN 60742; Cruells Talleres SL, Girona, Spain). Three representative homogeneous samples of the ground material were collected. One sample was immediately sent to the laboratory for determining DM content and the other 2 samples were refrozen at $-20^{\circ} \mathrm{C}$. Subsequently, samples were freeze-dried for $72 \mathrm{~h}$ and ground through a 1-mm screen until chemical analysis. The same procedure was applied to a different group of animals (10 animals per age) considered the validation body composition group (VG).

\section{Chemical Analysis}

The DM content of the ground material samples was determined by mixing a $5-\mathrm{g}$ sample with $20 \mathrm{~g}$ sea sand and $5 \mathrm{~mL}$ ethanol and then drying at $103^{\circ} \mathrm{C}$ during $24 \mathrm{~h}$ following the ISO 1442:1997 method (ISO, 1997). Those samples and diets were analyzed following AOAC methods (AOAC, 2000): DM (method 934.01), CP (Dumas method, N $\times 6.25$; method 968.06), ash (method 942.05), and fat (RD 609/1999 number 4 [Government of Spain, 1999], previous acid hydrolysis) The GE content of meat was determined using an adiabatic calorimetric bomb (model 6100; Parr Instrument Company, Moline, IL). The DE of the diets was estimated by using the digestibility coefficient for each raw material as described by Maertens et al . (2010).

\section{Statistical Analysis}

The statistical program SAS/STAT (SAS Inst. Inc., Cary, NC) was used for all statistical analysis. A Levene's test was done to test the homogeneity of
Table 1. Ingredients and chemical composition of lactating (Cunilactal Super ${ }^{1}$ [CLS]) and growing (standard growing rabbit diet $[\mathrm{CON}])$ feeds

\begin{tabular}{|c|c|c|}
\hline Diet & CLS & $\mathrm{CON}$ \\
\hline \multicolumn{3}{|l|}{ Ingredients composition, $\%$} \\
\hline Wheat bran & 30.0 & 30.0 \\
\hline Barley & 16.6 & 20.4 \\
\hline Sunflower meal & - & 10.6 \\
\hline Alfalfa & 29.3 & 13.0 \\
\hline Cereal straw & 2.0 & 5.00 \\
\hline Beet pulp & - & 15.0 \\
\hline Soybean oil & 0.68 & 1.50 \\
\hline Wheat & - & - \\
\hline Soybean meal 47 & 0.7 & - \\
\hline Molasses & 4.0 & - \\
\hline Whole-grain sunflower & 15 & - \\
\hline L-Threonine & - & 0.18 \\
\hline L-Lysine & 0.18 & 0.18 \\
\hline Sodium chloride & 0.30 & 0.50 \\
\hline Monocalcium phosphate & 0.41 & - \\
\hline Calcium carbonate & - & 1.23 \\
\hline Sepiolite & - & 2.00 \\
\hline Mineral and vitamin premix $A^{2}$ & 0.80 & - \\
\hline Mineral and vitamin premix $B^{3}$ & - & 0.50 \\
\hline \multicolumn{3}{|l|}{ Analyzed chenical composition, $\%$} \\
\hline DM & 89.7 & 89.9 \\
\hline$C P$ & 17.1 & 14.2 \\
\hline NDF & 32.0 & 34.6 \\
\hline $\mathrm{ADF}$ & 17.6 & 18.5 \\
\hline $\mathrm{ADL}$ & 4.47 & 4.15 \\
\hline Starch & 16.9 & 15.6 \\
\hline Fat & 3.30 & 3.55 \\
\hline Ash & 7.31 & 8.87 \\
\hline $\mathrm{DE},{ }^{4} \mathrm{kcal} / \mathrm{kg}$ & 2,450 & 2.463 \\
\hline Digestible protein ${ }^{3}$ & 11.5 & 9.81 \\
\hline
\end{tabular}

'Provided by NANTA (Griñon, Spain)

'Provided by Trouw Nutrition España (Tres Cantos, Spain). Mineral and vitamin composition (per kg of complete diet): $240 \mathrm{mg} \mathrm{S,} 240 \mathrm{mg} \mathrm{Mg}$ as $\mathrm{MgO}, 20 \mathrm{mg} \mathrm{Mu}$ as $\mathrm{MnO}, 75 \mathrm{mg} \mathrm{Zu}$ as $\mathrm{ZnO}, 180 \mathrm{mg} \mathrm{Cu}$ as $\mathrm{CuSO}_{4}+5 \mathrm{H}_{2} \mathrm{O}$. $1.1 \mathrm{mg} \mathrm{I}$ as KI, $0.5 \mathrm{mg}$ Co as $\mathrm{CoCO}_{3} \cdot \mathrm{H}_{2} \mathrm{O}, 0.06 \mathrm{mg} \mathrm{Se}$ as $\mathrm{SeO}_{2} 7.8 \mathrm{mg} \mathrm{Fe}$ as $\mathrm{FeCO}_{3}, 12,000$ IU vitamio $\mathrm{A}, 10,800 \mathrm{IU}$ vitamio $\mathrm{D}_{3}, 45 \mathrm{ng}$ vitamin $\mathrm{E}$ DL-alpha-tocopheryl acetate, $1.2 \mathrm{mg}$ vitamin $\mathrm{K}, 2 \mathrm{mg}$ vitamin $\mathrm{Bl}, 60 \mathrm{mg}$ vitanin $\mathrm{B}_{2}, 2 \mathrm{mg}$ vitamin $\mathrm{B}_{6}, 10 \mathrm{mg}$ vitamin $\mathrm{B}_{12}, 40 \mathrm{mg}$ niacin, $20 \mathrm{mg}$ calcium pantothenate, $18.4 \mathrm{mg}$ pantothenic acid, $5 \mathrm{mg}$ folic acid, $75 \mu \mathrm{g}$ biotin, $260 \mathrm{mg}$ choline chloride, $60 \mathrm{mg}$ robenidine hydrochloride (Cycostast 66G: Zoetis España, Alcobendas, Spain), $0.12 \mathrm{mg}$ butylated hydroxyanisole. $13.2 \mathrm{mg}$ butylated hydroxytoluene, and $38.4 \mathrm{mg}$ ethoxycuin.

${ }^{3}$ Provided by Trouw Nutrition Espanta (Tres Cantos, Spain). Mineral and vitamin composition (per kg of complete diet): $240 \mathrm{mg} \mathrm{S.} 240 \mathrm{mg} \mathrm{Mg}$ as MgO, 20 $\mathrm{mg} \mathrm{Mn}$ as $\mathrm{MnO}, 75 \mathrm{mg} \mathrm{Zn}$ as $\mathrm{ZnO}, 180 \mathrm{mg} \mathrm{Cu}$ as $\mathrm{CuSO}_{4} \cdot 5 \mathrm{H}_{2} \mathrm{O}, 1.1 \mathrm{mg} \mathrm{I}$ as $\mathrm{KI}$, $0.5 \mathrm{mg} \mathrm{Co}$ as $\mathrm{CoCO}_{3} \cdot \mathrm{H}_{2} \mathrm{O}, 0.06 \mathrm{mg} \mathrm{Se}$ as $\mathrm{SeO}_{2} .7 .8 \mathrm{mg} \mathrm{Fe}$ as $\mathrm{FeCO}_{3} .12,000$ IU vitamin $A, 10,800$ IL vitamin $D_{3}, 45 \mathrm{mg}$ vitamio $\mathrm{E}$ dl-alpha-tocopheryl acetate, $1.2 \mathrm{mg}$ vitamin $K, 2 \mathrm{mg}$ vitanin $B_{1}, 60 \mathrm{mg}$ vitaniin $B_{2}, 2 \mathrm{mg}$ vitanin $\mathrm{B}_{6,}, 10 \mathrm{mg}$ vitamin $\mathrm{B}_{1,2}, 40 \mathrm{mg}$ niacin, $20 \mathrm{mg}$ calcium pantothenate, $18.4 \mathrm{mg}$ pantothenic acid, $5 \mathrm{mg}$ folic acid, $75 \mu \mathrm{g}$ biotin, $260 \mathrm{mg}$ choline chloride, $10 \mathrm{mg}$ diclazuril $0.5 \mathrm{~g} / 100 \mathrm{~g}$ (Clinacox $0.5 \%$; Premix; Janssen Phannacentica N.V., Beerse, Belgium), $0.12 \mathrm{mg}$ butylated hydroxyanisole, $13.2 \mathrm{mg}$ butylated hydroxytoluene, and $38.4 \mathrm{mg}$ ethoxyguin.

${ }^{4}$ Estimated using the digestibility coelficients of Maertens et al. (2010). 
Table 2. Mean values of resistance (Rs), reactance $(\mathrm{Xc})$, impedance $(\mathrm{Z})$, distance between internal electrodes (D), animal body length (Len), and BW of the calibration body composition group animals $(n=30)$ at $25,35,49,63$, and $77 \mathrm{~d}$ of age

\begin{tabular}{llcccccc}
\hline \hline Age, $d$ & Item & Rs, $\Omega$ & Xc, $\Omega$ & $Z, \Omega$ & D, cm & Len, cm & BW, g \\
\hline 25 & Mean & 118 & 18.7 & 119 & 6.81 & 20.8 & 369 \\
& Min. & 87.5 & 13.0 & 88.6 & 5.25 & 18.0 & 231 \\
& Max. & 182 & 30.0 & 184 & 9.25 & 24.5 & 518 \\
& SD & 19.7 & 3.57 & 20.0 & 1.03 & 1.74 & 80.7 \\
& Mean & 84.6 & 16.6 & 86.2 & 9.28 & 25.9 & 780 \\
& Min. & 70.0 & 12.0 & 71.4 & 7.15 & 23.0 & 530 \\
& Max. & 105 & 20.5 & 107 & 11.5 & 28.5 & 1.015 \\
& SD & 8.26 & 2.01 & 8.44 & 1.12 & 1.37 & 106 \\
49 & Mean & 74.3 & 17.5 & 76.4 & 11.3 & 31.8 & 1.500 \\
& Min. & 52.5 & 11.0 & 53.6 & 8.50 & 25.0 & 1.136 \\
& Max. & 103 & 23.0 & 105 & 14.5 & 34.5 & 1.842 \\
& SD & 12.3 & 3.35 & 12.6 & 1.47 & 1.84 & 159 \\
63 & Mean & 69.1 & 17.6 & 71.4 & 11.6 & 36.7 & 2.125 \\
& Min. & 38.5 & 11.0 & 40.5 & 8.25 & 32.5 & 1.542 \\
& Max. & 92.5 & 28.0 & 95.2 & 14.5 & 39.0 & 2.436 \\
& SD & 12.7 & 3.99 & 13.1 & 1.66 & 1.59 & 237 \\
77 & Mean & 72.1 & 20.5 & 75.2 & 15.2 & 38.6 & 2.572 \\
& Min. & 42.0 & 13.5 & 47.4 & 11.5 & 32.0 & 1.521 \\
& Max. & 97.0 & 37.0 & 98.8 & 19.0 & 42.0 & 3.138 \\
& SD & 13.7 & 4.79 & 13.1 & 1.88 & 2.63 & 362 \\
\hline \multirow{6}{*}{35} & & & & & & &
\end{tabular}

${ }^{1} \mathrm{Min} .=$ minimum value; $\mathrm{Max} .=$ maximum value.

variances. Linear and quadratic responses of body composition were studied using the PROC GLM method.

Repeatability $\left(\mathbf{S}_{\mathbf{R}}\right.$; intraseries variability of BIA measurements within rabbit) was estimated by the VARCOM procedure of SAS (SAS Inst. Inc.) and was calculated as $\mathrm{S}_{\mathrm{R}}=\left(\left[\left(\mathrm{S}_{\mathrm{e}}\right)^{2}\right]^{1 / 2}\right.$, in which $\mathrm{S}_{\mathrm{e}}$ was the expected variance of error. The $\mathrm{CV}$ of repeatability $\left(\mathrm{CV}_{\mathrm{R}}\right)$ was calculated as the relation between $S_{R}$ and the mean value of the BIA measurements, expressed as a percentage.

Correlation coefficients between BIA measurements and body composition were calculated using the CORR procedure. To select the regression models that best explained the variation of the dependent variables, the RSQUARE option of PROC REG was used, using the chemical composition data of the $\mathrm{CG}$ animals. The dependent variables included were water (expressed as $\%$ and as g), CP, ash, fat (expressed as \% DM and $\mathrm{g}$ ), and energy ( $\mathrm{kJ} / 100 \mathrm{~g} \mathrm{DM}$ and $\mathrm{MJ})$. Independent variables chosen as candidates to be included in the regression model were age, BW, BW ${ }^{2}$, Len, $\mathrm{Len}^{2}, \mathrm{D}, \mathrm{D}^{2}, \mathrm{Rs}$, $\mathrm{Rs}^{2}, \mathrm{Xc}, \mathrm{Xc}^{2}, \mathrm{Z}, \mathrm{Z}^{2}$, voll ( $\left.\mathrm{D}^{2} / \mathrm{Rs}\right)$, and vol $2\left(\mathrm{D}^{2} / \mathrm{Z}\right)$. The model was selected using the Mallows' Cp statistic ( $C$ p Mallows, 1973), which should be lower than or equal to $p+1$ ( $p$ is the number of independent variables included in the model) for avoiding biases because of omission of relevant explanatory variables. When this criteria was satisfied, the model with the minimum value
Table 3. Mean values of resistance (Rs), reactance $(\mathrm{Xc})$, impedance $(\mathrm{Z})$, distance between internal electrodes (D), animal body length (Len), and BW of the validation body composition group animals $(n=10)$ at $25,35,49,63$, and $77 \mathrm{~d}$ of age

\begin{tabular}{llcccccc}
\hline \hline Age, d & Item $^{1}$ & Rs, $\Omega$ & Xc, $\Omega$ & $Z, \Omega$ & D, cm & Len, cm & BW, g \\
\hline 25 & Mean & 115 & 18.4 & 116 & 6.50 & 18.5 & 424 \\
& Min. & 88.5 & 12.5 & 89.4 & 5.50 & 17.5 & 326 \\
& Max. & 135 & 22.0 & 136 & 8.25 & 20.0 & 481 \\
& SD & 14.4 & 2.98 & 14.7 & 0.76 & 0.76 & 49.4 \\
35 & Mean & 86.7 & 18.7 & 88.7 & 7.43 & 24.8 & 799 \\
& Min. & 71.5 & 16.0 & 73.5 & 6.25 & 23.0 & 660 \\
& Max. & 117 & 23.5 & 119 & 8.75 & 26.5 & 894 \\
& SD & 14.0 & 2.34 & 14.1 & 0.71 & 1.14 & 72.4 \\
49 & Mean & 82.0 & 19.7 & 84.3 & 10.7 & 33.5 & 1.475 \\
& Min. & 57.5 & 14.0 & 60.0 & 8.25 & 31.5 & 1.326 \\
& Max. & 96.0 & 23.5 & 98.8 & 13.3 & 35.0 & 1.596 \\
& SD & 10.3 & 2.81 & 10.45 & 1.54 & 1.12 & 86.9 \\
63 & Mean & 99.2 & 26.7 & 103.0 & 14.5 & 32.4 & 2.086 \\
& Min. & 58.0 & 23.0 & 66.7 & 11.5 & 24.0 & 1.503 \\
& Max. & 134 & 33.0 & 137 & 18.5 & 35.0 & 2.358 \\
& SD & 20.3 & 3.95 & 19.1 & 1.97 & 3.54 & 263 \\
77 & Mean & 62.3 & 18.2 & 64.9 & 15.4 & 31.3 & 2.426 \\
& Min. & 50.0 & 15.0 & 52.5 & 13.3 & 23.0 & 1.995 \\
& Max. & 77.5 & 20.5 & 80.2 & 17.0 & 36.0 & 3.030 \\
& SD & 8.85 & 2.19 & 8.99 & 1.53 & 5.20 & 325 \\
\hline \multirow{6}{*}{4} & & & & & & &
\end{tabular}

${ }^{1}$ Min. = minimum value: Max. $=$ maximum value

of the statistics - average prediction mean squared error (Sp; Hocking, 1976), final prediction error (Hocking, 1976; Judge et al., 1980), Amemiya's prediction criteria (Judge et al., 1980; Amemiya, 1985), and Akaike's information criterion (Akaike, 1969)-was selected After selecting the independent variables to be included in the multiple linear regression (MLR) models, parameter estimation was performed by using PROC REG.

For validating the regression equations with independent data, the chemical composition data of the VG animals were used. The prediction accuracy of the equations was measured by using the mean prediction error (MPE), which was calculated as the root square of the sum of the squares of the residuals between the actual values of the body composition parameter, estimated by chemical analysis techniques, and the predicted values, divided by the number of observations Relative mean prediction error (RMPE; \%) was calculated as the ratio between MPE and the average of the actual body composition parameter values. For detecting multicollinearity problems among independent variables included in the MLR equations, the variance inflation factor (VIF) and the COLLIN option of PROC REG were used to obtain the values of VIF and the condition index for the independent variables included in each model. If severe multicollinearity problems were detected, partial least squares (PLS) 
Table 4. Repeatability $\left(S_{R}\right)$ and $C V$ of repeatability $\left(\mathrm{CV}_{\mathrm{R}}\right)$ of resistance $(\mathrm{Rs})$ and reactance $(\mathrm{Xc})$

\begin{tabular}{lcc}
\hline \hline Variable & $\mathrm{S}_{\mathrm{R}} \Omega$ & $\mathrm{CV}_{\mathrm{R}} \%$ \\
\hline $\mathrm{Rs}, \Omega$ & 16.7 & 20.0 \\
$\mathrm{Xe}, \Omega$ & 3.90 & 21.5 \\
\hline
\end{tabular}

regression was performed using PROC PLS. The data from the VG animals also allow evaluation of the prediction accuracy of the PLS equations. The difference between observed and estimated values obtained with prediction equations (MLR and PLS) in the validation group was compared by using a paired $t$ test

\section{RESULTS}

\section{Impedance Measurements and Repeatability}

The mean values, the range, and the variability of Rs, Xc, Z, D, Len, and BW per age of the CG animals are shown in Table 2 . As the age of the animals was increased, the values of Rs and $Z$ numerically decreased In contrast, $\mathrm{Xc}$ increased with the age.

In Table 3, the values of these parameters for the VG animals are shown. Values were similar to those obtained from the CG animals group, and similarly, as the age of the animals increased, the values of Rs and $\mathrm{Z}$ numerically decreased. Reactance remained practically constant with age.

In Table 4 , the values of $S_{R}(\Omega)$ and CVR (\%) of $R s$ and $X c$ are shown. The SR value was around 4 times higher for Rs than for $\mathrm{Xc}$. The $\mathrm{CV}_{\mathrm{R}}$ values of $\mathrm{Rs}$ and $\mathrm{Xc}$ were similar.

Animals' ADFI, ADG, and feed conversion rate per period are shown in Table 5 . Thirty animals per age were slaughtered to analyze body composition at each age; therefore, the number of control animals decreased

\section{Body Composition}

The results of BW and the analyzed body composition of the CG animals are shown in Table 6. The BW increased in a linear and quadratic manner with increasing age (linear, $P<0.000$ I, and quadratic, $P<0.0054$ ). The body composition also changed with age. The water, protein, and ash body content, expressed as percent $\mathrm{DM}$, linearly decreased (linear, $P<0.0001$ ) with the age. A maximum value of water content $(73.6 \%$; quadratic, $P<0.000 \mathrm{I})$ and ash content $(12.7 \% \mathrm{DM}$; quadratic, $P=0.0138$ ) was found at $35 \mathrm{~d}$. In contrast, fat and GE content increased (linear, $P<0.0001$ ) with age, but both traits also had a minimum value at $35 \mathrm{~d}(20.6 \%$ DM [quadratic, $P=0.068$ ] and $2,097 \mathrm{~kJ} / 100 \mathrm{~g} \mathrm{DM}$ [quadratic, $P<0.0001$ ], respectively).
Table 5. Average daily feed intake, ADG, and feed conversion rate (FCR) of the calibration group animals from 35 to $77 \mathrm{~d}$

\begin{tabular}{llccc}
\hline \hline Period & Item & ADFI. g/d & ADG, g/d & FCR \\
\hline $35-49 \mathrm{~d}$ & Mean & 106 & 51.1 & 2.11 \\
& SD & 18.1 & 10.2 & 0.26 \\
& No. & 30 & 30 & 30 \\
$49-63 \mathrm{~d}$ & Mean & 131 & 42 & 2.87 \\
& SD & 29.93 & 12.6 & 4.36 \\
& No. & 30 & 30 & 30 \\
$63-77 \mathrm{~d}$ & Mean & 150 & 40.1 & 3.87 \\
& SD & 31.0 & 9.99 & 0.87 \\
& No. & 30 & 30 & 30 \\
$35-77 \mathrm{~d}$ & Mean & 127 & 43.3 & 2.73 \\
& SD & 21.0 & 6.71 & 1.93 \\
& No. & 30 & 30 & 30 \\
\hline
\end{tabular}

When the body composition was expressed in grams, or in megajoules, in the case of GE, all parameters increased with age in a linear and quadratic manner (linear, $P<0.000 \mathrm{I}$, and quadratic, $P<0.005$ ), except $\mathrm{CP}$, which grew only linearly.

\section{Correlation between Variables}

Results of the correlation analysis between variables are shown in Table 7. Age had positive correlations with fat and energy content $(r=0.78, P<0.0001$, and $r=0.81$, $P<0.0001$, respectively) and negative correlations with water, protein, and ash content $(r=-0.79, P<0.0001$; $r=-0.80, P<0.0001$; and $r=-0.68, P<0.0001$, respectively). Reactance was negatively correlated with water, ash, and CP content $(r=-0.32, P<0.000 \mathrm{I} ; r=-0.20$, $P<0.05$; and $r=-0.26, P<0.01$, respectively) and positively correlated with fat and GE $(r=0.23$ and $r=0.24$, respectively; $P<0.01$ ). Otherwise, Rs was positively correlated with water, ash, and CP content $(r=0.31, P<$ $0.001 ; r=0.28, P<0.001$; and $r=0.37, P<0.0001$, respectively) and negatively correlated with fat and energy ( $r=-0.36$ and $r=-0.35$, respectively; $P<0.0001$ ).

\section{Regression Equations}

The regression equations obtained with MLR from the $\mathrm{CG}$ are shown in Tables 8,9, and 10 , with the estimate, $\mathrm{SE}$, and $P$-values of each variable and the $R^{2}$, residual SD, $\mathrm{CV}, \mathrm{Cp}$, and probability of the model of each equation.

\section{Detection of Multicollinearity}

High levels of multicollinearity were observed among the variables included in all the MLR prediction equations (VIF $>10$ and condition index $>30$ ), which is the reason why PLS equations were calculated. 
Table 6. Body weight and analyzed animal body composition (expressed as a percentage and in grams) of the calibration body composition group rabbits at $25,35,49,63$, and $77 \mathrm{~d}$ of age $(n=30)$

\begin{tabular}{|c|c|c|c|c|c|c|c|c|}
\hline \multirow[b]{2}{*}{ Variable } & \multicolumn{5}{|c|}{ Age, d } & \multirow[b]{2}{*}{ SEM } & \multirow{2}{*}{$\begin{array}{c}P \text {-value, } \\
\text { linear }\end{array}$} & \multirow{2}{*}{$\begin{array}{l}P \text {-value, } \\
\text { quadratic }{ }^{2}\end{array}$} \\
\hline & 25 & 35 & 49 & 63 & 77 & & & \\
\hline BW, g & 369 & 780 & 1.505 & 2,125 & 2,572 & 38.8 & 0.0001 & 0.0054 \\
\hline \multicolumn{9}{|c|}{ Chemical body composition, \% DM } \\
\hline Water. \% & 72.8 & 73.6 & 70.9 & 69.1 & 65.9 & 0.41 & 0.0001 & 0.0001 \\
\hline Protein & 59.3 & 59.8 & 55.3 & 51.1 & 48.5 & 0.57 & 0.0001 & 0.1359 \\
\hline Fat & 22.3 & 20.6 & 25.9 & 34.4 & 36.0 & 0.79 & 0.0001 & 0.0682 \\
\hline Ash & 11.8 & 12.7 & 11.2 & 10.3 & 9.50 & 0.19 & 0.0001 & 0.0138 \\
\hline $\mathrm{GE}, \mathrm{kJ} / 100 \mathrm{~g} \mathrm{DM}$ & 2,147 & 2.097 & 2,210 & 2,393 & 2,505 & 18.1 & 0.0001 & 0.0001 \\
\hline \multicolumn{9}{|c|}{ Chemical body composition, $g$} \\
\hline Water & 269 & 573 & 1,066 & 1,466 & 1,687 & 26.2 & 0.0001 & 0.0001 \\
\hline Protein & 58.8 & 123 & 242.1 & 334 & 425 & 8.45 & 0.0001 & 0.1762 \\
\hline Fat & 22.6 & 42.9 & 115 & 232 & 327 & 8.71 & 0.0001 & 0.0006 \\
\hline Ash & 11.8 & 26.1 & 48.8 & 67.0 & 81.8 & 1.46 & 0.0001 & 0.0011 \\
\hline $\mathrm{GE}, \mathrm{MJ}$ & 2.15 & 4.34 & 9.75 & 15.9 & 22.4 & 0.64 & $<0.0001$ & 0.0034 \\
\hline
\end{tabular}

${ }^{1}$ Probability of linear response to animal age.

${ }^{2}$ Probability of quadratic response to animal age.

In Tables II and 12, the regression coefficients of the PLS equations are shown. Multiple coefficient of determination values were $0.80,0.78,0.71,0.83$, and 0.84 for water, protein, ash, fat, and energy content, respectively, when they were expressed as percent DM or kilojoules per $100 \mathrm{~g} \mathrm{DM}$ for energy and $0.99,0.99$, $0.98,0.97$, and 0.99 , respectively, when they were expressed in grams or megajoules for energy.

\section{Validation of Prediction Equations}

The comparative results obtained from the external validation with independent data from the MLR and PLS equations are shown in Table 13. The adjustment of the prediction equations obtained by MLR and PLS for the animal chemical body composition was higher $\left(R^{2}>0.90\right)$ when the animal chemical body compositions were expressed in grams than when they were expressed as a percentage. The RMPE values of all equations were similar between both methods but higher when the chemical body composition was expressed in grams rather than as a percentage.

In Table 14, the comparison of the analyzed values vs. the predicted values obtained by MLR and PLS equations of animal chemical body composition are presented. For MLR predictions, an underestimation of the ash content $(11.3 \mathrm{vs} .12 .2 \% \mathrm{DM} ; P<0.0001)$ was found. In contrast, an overestimation of the fat ( $26.3 \mathrm{vs}$. $23.5 \% \mathrm{DM}$ and 123 vs. $110 \mathrm{~g} ; P<0.001)$ and the energy content $(2,230$ vs. $2,200 \mathrm{~kJ} / 100 \mathrm{~g} \mathrm{DM} ; P=0.0018)$ was found. Compared with MLR results, PLS predictions led to differences similar to those of the analyzed values

Distribution of residuals obtained by differences between analyzed and predicted data by using

Table 7. Correlation matrix between bioelectrical impedance analysis and body composition expressed as a percentage of calibration group animals $(n=150)^{1}$

\begin{tabular}{|c|c|c|c|c|c|c|c|c|c|c|c|}
\hline & $\begin{array}{c}\mathrm{Yc} \\
\Omega\end{array}$ & $\begin{array}{c}\text { Rs. } \\
\mathbf{\Omega}\end{array}$ & $\begin{array}{c}\text { Water. } \\
\text { \%o }\end{array}$ & $\begin{array}{l}\text { Protein, } \\
\% \text { DMI }\end{array}$ & $\begin{array}{c}\text { Fat. } \\
\% \text { DM }\end{array}$ & $\begin{array}{c}\text { Ash. } \\
\% \text { DM }\end{array}$ & $\begin{array}{c}\text { Energy } \\
\mathrm{kJ} 100 \mathrm{~g} \text { DM }\end{array}$ & $\begin{array}{c}\mathrm{BW}, \\
\mathrm{g}\end{array}$ & $\begin{array}{c}\text { Age, } \\
\text { d }\end{array}$ & $\begin{array}{l}\text { Len. } \\
\mathrm{cm}\end{array}$ & $\begin{array}{l}\mathrm{D} \\
\mathrm{mi}\end{array}$ \\
\hline$\lambda e, \Omega$ & 1 & $0.39 \dagger$ & $-0.32 \dagger$ & $-0.26^{* *}$ & $0.23^{* *}$ & $-0.20^{*}$ & $0.24^{* *}$ & $0.18^{*}$ & $0.18^{*}$ & 0.12 & $0.30^{* * * *}$ \\
\hline $\mathrm{Rs}, \Omega$ & & 1 & $0.31 * * *$ & 0.374 & $-0.36 \uparrow$ & $0.28 * * *$ & $-0.35 \dagger$ & -0.614 & $-0.62 \dagger$ & $-0.66 \dagger$ & -0.454 \\
\hline Water, $\%$ & & & 1 & 0.894 & -0.914 & $0.79+$ & $-0.89+$ & -0.854 & $-0.79+$ & $-0.78 \dagger$ & -0.694 \\
\hline Protein, \% DM & & & & 1 & $-0.944^{4}$ & $0.80 \dagger$ & $-0.91 \dagger$ & -0.864 & $-0.80 \dagger$ & $-0.81 \dagger$ & -0.694 \\
\hline Fat, \% DM & & & & & 1 & $-0.84 \dagger$ & $0.92 \dagger$ & 0.864 & $0.78 \dagger$ & $0.80 \dagger$ & $0.64 \uparrow$ \\
\hline Ash, $\%$ DM & & & & & & 1 & $-0.87+$ & -0.764 & $-0.68 \dagger$ & $-0.70 \dagger$ & -0.584 \\
\hline Energy, $\mathrm{kJ} / 100 \mathrm{~g} \mathrm{DM}$ & & & & & & & 1 & 0.884 & $0.81 \dagger$ & $0.80 \dagger$ & $0.66 \uparrow$ \\
\hline $\mathrm{BW}, \mathrm{g}$ & & & & & & & & 1 & $0.97 \dagger$ & $0.96 \dagger$ & $0.84 \uparrow$ \\
\hline Age, d & & & & & & & & & 1 & $0.94 \dagger$ & 0.864 \\
\hline Len, en & & & & & & & & & & 1 & $0.84 \uparrow$ \\
\hline D. cm & & & & & & & & & & & 1 \\
\hline
\end{tabular}

${ }_{1} \mathrm{Ye}=$ reactance; $\mathrm{Rs}=$ resistance; Len $=$ body length: $\mathrm{D}=$ distance between intemal electrodes.

${ }^{*} P<0.05 ; * * P<0.01 ; * * * P<0.001 ; \uparrow P<0.0001$. 
Table 8. Regression coefficients and SE for equations determined by multiple linear regression for predicting body water and protein content $(n=150)$

\begin{tabular}{|c|c|c|c|c|c|c|c|c|c|}
\hline $\begin{array}{l}\text { Dependent } \\
\text { variable }\end{array}$ & $\begin{array}{c}\text { Independent } \\
\text { variable }^{1}\end{array}$ & Estimate & $\mathrm{SE}$ & $P$-value & $R^{2}$ & $\operatorname{rsd}^{2}$ & $\mathrm{CV}$ & $P \mathbf{m}^{3}$ & $\mathrm{Cp}_{\mathrm{p}}^{4}$ \\
\hline \multirow[t]{8}{*}{ Water, \% } & Intercept & 70.2 & 1.92 & $<0.0001$ & 0.85 & 1.33 & 1.89 & $<0.0001$ & 6.05 \\
\hline & Age & 0.06 & 0.022 & 0.007 & & & & & \\
\hline & $\mathrm{BW}^{2}$ & $-1.27 \backslash 10^{-6}$ & $1.28 \backslash 10^{-i}$ & $<0.0001$ & & & & & \\
\hline & Len ${ }^{2}$ & -0.002 & $9.57 \backslash 10^{-4}$ & 0.04 & & & & & \\
\hline & $\mathrm{Xc}^{2}$ & -0.007 & 0.0029 & 0.02 & & & & & \\
\hline & Rs & -0.66 & 0.34 & 0.05 & & & & & \\
\hline & $\mathrm{Rs}^{2}$ & $-3.83 \backslash 10^{-4}$ & $1.31 \backslash 10^{-4}$ & 0.004 & & & & & \\
\hline & Z & 0.74 & 0.35 & 0.04 & & & & & \\
\hline \multirow[t]{8}{*}{ Water, $g$} & Intercept & 11.6 & 26.0 & 0.66 & 0.99 & 21.3 & 2.13 & 0.0001 & 5.76 \\
\hline & Age & 0.95 & 0.38 & 0.01 & & & & & \\
\hline & $\mathrm{BW}$ & 0.85 & 0.022 & $<0.0001$ & & & & & \\
\hline & $\mathrm{BW}^{2}$ & $-6.55 \backslash 10^{-5}$ & $4.33 \backslash 10^{-6}$ & $<0.0001$ & & & & & \\
\hline & Len & -3.02 & 1.19 & 0.013 & & & & & \\
\hline & $\mathrm{Xc}$ & -3.80 & 1.63 & 0.02 & & & & & \\
\hline & Rs & -9.01 & 3.98 & 0.02 & & & & & \\
\hline & Z & 9.42 & 4.18 & 0.03 & & & & & \\
\hline \multirow[t]{6}{*}{ Protein \% DM } & Intercept & 67.1 & 3.07 & $<0.0001$ & 0.79 & 2.56 & 1.89 & 0.0001 & 0.28 \\
\hline & Age & 0.098 & 0.04 & 0.03 & & & & & \\
\hline & $\mathrm{BW}$ & -0.007 & 0.003 & 0.007 & & & & & \\
\hline & $\mathrm{BW}^{2}$ & $-3.87 \backslash 10^{-i}$ & $4.80 \backslash 10^{-i}$ & 0.42 & & & & & \\
\hline & Len & -0.061 & 0.14 & 0.66 & & & & & \\
\hline & Z & -0.050 & 0.013 & 0.0003 & & & & & \\
\hline \multirow[t]{5}{*}{ Protein g } & Intercept & -2.98 & 12.7 & 0.81 & 0.99 & 13.5 & 2.13 & 0.0001 & -0.87 \\
\hline & $\mathrm{BW}$ & 0.13 & 0.012 & $<0.0001$ & & & & & \\
\hline & $\mathrm{BW}^{2}$ & $7.51 \backslash 10^{-6}$ & $2.33 \backslash 10^{-6}$ & 0.002 & & & & & \\
\hline & vol 2 & 3.39 & 2.09 & 0.11 & & & & & \\
\hline & Len & 0.51 & 0.75 & 0.49 & & & & & \\
\hline
\end{tabular}

\footnotetext{
${ }^{1}$ Len $=$ body length; $\mathrm{Xc}=$ reactance; $\mathrm{Rs}=$ resistance; $Z=$ impedance; vol $2=(\text { distance between internal electrodes })^{2} \mathrm{Z}$.

rrsd = residual SD.

${ }^{3} \mathrm{Pm}=$ probability of the model.

${ }^{4}$ Mallows' Cp statistic (Mallows, 1973)
}

MLR equations body fat and protein content, expressed as percent DM and grams, are shown in Fig 2 . Distribution of residuals was more homogenous when protein and fat content was expressed as a percentage than when expressed as grams. In the case of percent DM equations, when the protein content of a carcass was higher than $60 \% \mathrm{DM}$, there was an underestimation in the prediction of protein and an overestimation when the protein content was lower than $45 \% \mathrm{DM}$. In contrast, when fat content was lower $20 \% \mathrm{DM}$, the equation overestimates the carcass fat content.

\section{DISCUSSION}

\section{Impedance Measurements and Repeatability}

The $\mathrm{Z}$ parameter measures the voltage reduction that occurs when an electric current passes through an object. This reduction depends on the body composition when a relatively constant geometry is assumed for all animals and uses a constant alternating electrical signal of $800 \mu \mathrm{A}$ at $50 \mathrm{kHz}$ (Lukaski et al., 1985). Water, ash, and protein body content are better conductors of electrical current than fat. Therefore, it would be expected that at the same age, a fat animal would have a higher $Z$ value than a lean animal. However, in this work, the geometry of the rabbits was not constant because they were growing and, thus, increasing their volume from 25 to $77 \mathrm{~d}$ of age. This is the reason why Rs and $\mathrm{Xc}$ decreased from 25 to $77 \mathrm{~d}$. As was explained by Lukaski et al. (1985), the volume for an alternating current is inversely proportional to the Rs and $\mathrm{Xc}$, and this equation shows that volume $=\mathrm{D}^{2} /$ $\left(\mathrm{Rs}^{2}+\mathrm{Xc}^{2}\right)^{5}$. Therefore, when the volume increases, values of Rs and Xc decrease. This relationship should also explain why $\mathrm{Rs}$ and $\mathrm{Xc}$ values of growing rabbits were lower than those obtained in rabbits does by Pereda (2010), even though the body fat content of the adult animals was higher and the opposite result would be expected. The same occurs with BIA val- 
Table 9. Regression coefficients and SE of the equations determined by multiple linear regression for predicting body ash and fat content $(n=150)$

\begin{tabular}{|c|c|c|c|c|c|c|c|c|c|}
\hline $\begin{array}{l}\text { Dependent } \\
\text { variable }\end{array}$ & $\begin{array}{c}\text { Independent } \\
\text { variable }\end{array}$ & Estimate & SE & $P$-value & $R^{2}$ & $\mathrm{rsd}^{2}$ & $\mathrm{CV}$ & $P \mathbf{n}^{3}$ & $C p^{4}$ \\
\hline \multirow[t]{8}{*}{$\overline{A s h, \% \mathrm{DM}}$} & Intercept & 2.75 & 2.73 & 0.31 & 0.71 & 0.86 & 7.75 & $<0.0001$ & 4.91 \\
\hline & Age & 0.07 & 0.02 & 0.0002 & & & & & \\
\hline & $\mathrm{BW}$ & -0.0028 & 0.001 & 0.01 & & & & & \\
\hline & $\mathrm{BW}^{2}$ & $2.04 \cdot 10^{-8}$ & $2.39 \cdot 10^{-7}$ & 0.93 & & & & & \\
\hline & Leo & 0.64 & 0.20 & 0.002 & & & & & \\
\hline & $\operatorname{Len}^{2}$ & -0.011 & 0.003 & 0.0005 & & & & & \\
\hline & voll & 0.63 & 0.62 & 0.32 & & & & & \\
\hline & vol2 & -0.68 & 0.72 & 0.35 & & & & & \\
\hline \multirow[t]{5}{*}{ Ash, g } & Intercept & 0.35 & 2.50 & 0.89 & 0.98 & 13.5 & 5.79 & $<0.0001$ & 4.45 \\
\hline & Age & 0.21 & 0.07 & 0.0019 & & & & & \\
\hline & $\mathrm{BW}$ & 0.025 & 0.001 & $<0.0001$ & & & & & \\
\hline & $\mathrm{Xe}$ & 0.35 & 0.11 & 0.004 & & & & & \\
\hline & Z & -0.08 & 0.02 & 0.001 & & & & & \\
\hline \multirow[t]{7}{*}{ Fat. $\%$ DM } & Intercept & 40.8 & 11.3 & 0.0004 & 0.83 & 3.23 & 11.7 & $<0.0001$ & 3.76 \\
\hline & Age & -0.26 & 0.06 & $<0.0001$ & & & & & \\
\hline & $\mathrm{BW}$ & 0.01 & 0.004 & 0.01 & & & & & \\
\hline & $\mathrm{BW}^{2}$ & $3.58 / 10^{-7}$ & $9.02 / 10^{-7}$ & 0.69 & & & & & \\
\hline & Len & -1.72 & 0.77 & 0.03 & & & & & \\
\hline & Len $^{2}$ & 0.03 & 0.01 & 0.005 & & & & & \\
\hline & $Z$ & 0.04 & 0.02 & 0.03 & & & & & \\
\hline \multirow[t]{5}{*}{ Fat, $g$} & Intercept & 33.0 & 18.3 & 0.074 & 0.97 & 22.7 & 15.6 & $<0.0001$ & 0.54 \\
\hline & Age & -2.10 & 0.36 & $<0.0001$ & & & & & \\
\hline & $\mathrm{BW}^{2}$ & $5.38 / 10^{-5}$ & $2.18 \cdot 10^{-6}$ & $<0.0001$ & & & & & \\
\hline & $\operatorname{Len}^{2}$ & 0.06 & 0.016 & 0.0004 & & & & & \\
\hline & $Z$ & 0.09 & 0.11 & 0.43 & & & & & \\
\hline
\end{tabular}

${ }^{1}$ Len $=$ body length; $\mathrm{Xc}=$ reactance; $Z=$ impedance; voll $=(\text { distance between internal electrodes })^{2} / \mathrm{resistance;} \mathrm{vol2}=($ distance between internal electrodes) $\hat{2} Z \mathrm{Z}$.

$\hat{T}_{\mathrm{TSd}}=$ residual SD.

${ }^{B_{P} \mathbf{n}}=$ probability of the model.

${ }^{4}$ Mallows ${ }^{\circ}$ Cp statistic (Mallows, 1973)

Table 10. Regression coefficients and $\mathrm{SE}$ of the equations determined by multiple linear regression for predicting body energy content $(n=150)$

\begin{tabular}{|c|c|c|c|c|c|c|c|c|c|}
\hline $\begin{array}{l}\text { Dependent } \\
\text { variable }\end{array}$ & $\begin{array}{c}\text { Independent } \\
\text { variablel }\end{array}$ & Estimate & SE & $P$-value & $R^{2}$ & $\mathrm{rsd}^{2}$ & $\mathrm{CV}$ & $P \mathbf{n}^{3}$ & $C p^{4}$ \\
\hline \multirow{8}{*}{$\begin{array}{l}\text { Energy. } \\
\text { kJ } 100 \mathrm{~g} \mathrm{DM}\end{array}$} & Intercept & 2.844 & 228 & $<0.0001$ & 0.86 & 70.0 & 3.09 & $<0.0001$ & 4.28 \\
\hline & Age & -3.01 & 1.42 & 0.04 & & & & & \\
\hline & BW & 0.0996 & 0.0863 & 0.25 & & & & & \\
\hline & $\mathrm{BW}^{2}$ & $3.80 / 10^{-5}$ & $1.94 / 10^{-5}$ & 0.05 & & & & & \\
\hline & Len & -54.2 & 16.4 & 0.001 & & & & & \\
\hline & $\operatorname{Len}^{2}$ & 0.99 & 0.25 & 0.0001 & & & & & \\
\hline & Xo & 1.15 & 1.60 & 0.47 & & & & & \\
\hline & vol2 & -15.1 & 12.4 & 0.23 & & & & & \\
\hline \multirow[t]{7}{*}{ Energy, MJ } & Intercept & -0.90 & 0.93 & 0.33 & 0.99 & 0.79 & 7.34 & $<0.0001$ & 4.58 \\
\hline & Age & -0.04 & 0.01 & 0.003 & & & & & \\
\hline & $\mathrm{BW}^{2}$ & $2.83 \cdot 10^{-6}$ & $7.22 / 10^{-8}$ & $<0.0001$ & & & & & \\
\hline & Len & 0.17 & 0.03 & $<0.0001$ & & & & & \\
\hline & Xe & 0.16 & 0.06 & 0.005 & & & & & \\
\hline & Rs & 0.43 & 0.14 & 0.003 & & & & & \\
\hline & Z & -0.44 & 0.15 & 0.003 & & & & & \\
\hline
\end{tabular}

${ }^{1}$ Len = body length: $\lambda c=$ reactance: $R s=$ resistance: $Z=$ inpedance: vol $2=(\text { distance between internal electrodes })^{2} / Z$.

TSd = residual SD.

${ }^{3} \mathrm{Pn}=$ probability of the model.

${ }^{4}$ Mallows' Cp statistic (Mallows, 1973) 
Table 11. Regression coefficients and SE of the equations determined by partial least squares for predicting body chemical composition, expressed as a percentage $(n=150)$

\begin{tabular}{|c|c|c|c|c|c|}
\hline Independent variable & Water, $\%$ & Protein. \% DM & Ash, \% DM & Fat, \% DM & Energy, $\mathrm{kJ} / 100 \mathrm{~g}$ DM \\
\hline Intercept & 65.1 & 63.8 & 5.24 & 23.3 & 2,077 \\
\hline Age & $7.41,10^{-2}$ & 0.024 & 0.067 & -0.22 & -1.26 \\
\hline $\mathrm{BW}$ & $-7.67 \cdot 10^{-4}$ & $-2.86 / 10^{-3}$ & $-3.35 \cdot 10^{-3}$ & $3.84 \cdot 10^{-3}$ & 0.068 \\
\hline $\mathrm{BW}^{2}$ & $-1.01 / 10^{-6}$ & $-1.09 \cdot 10^{-6}$ & $-1.33 / 10^{-7}$ & $2.06 / 10^{-7}$ & $5.90 / 10^{-5}$ \\
\hline Len & 0.405 & -0.051 & 0.49 & 0.12 & -2.76 \\
\hline $\operatorname{Len}^{2}$ & $-8.37 / 10^{-3}$ & $-1.11 \backslash 10^{-3}$ & $-8.05 / 10^{-3}$ & $6.08 \cdot 10^{-3}$ & 0.064 \\
\hline $\mathrm{Xo}$ & $-4.66 / 10^{-2}$ & $5.75 / 10^{-3}$ & 0.023 & -0.26 & -1.98 \\
\hline Rs & $-1.54 / 10^{-2}$ & $4.22 / 10^{-3}$ & 0.026 & -0.048 & 0.29 \\
\hline Z & $9.92 / 10^{-2}$ & 0.0057 & $-8.36 / 10^{-3}$ & -0.043 & 0.31 \\
\hline $\mathrm{Xe}^{2}$ & $-2.89 \cdot 10^{-3}$ & $-6.12,10^{-4}$ & $-4.72 / 10^{-3}$ & $5.16 / 10^{-3}$ & $9.00 \cdot 10^{-3}$ \\
\hline $\mathrm{Rs}^{2}$ & $-2.17 \cdot 10^{-4}$ & $-1.17 \cdot 10^{-4}$ & $5.01 / 10^{-5}$ & $3.80 \cdot 10^{-4}$ & $1.52 \cdot 10^{-3}$ \\
\hline$z^{2}$ & $-2.15 / 10^{-4}$ & $-1.11 \backslash 10^{-4}$ & $4.03 \cdot 10^{-5}$ & $3.77 \cdot 10^{-4}$ & $1.50 \cdot 10^{-3}$ \\
\hline voll & 3.49 & 0.31 & 0.52 & $7.33 \cdot 10^{-3}$ & -8.22 \\
\hline vol2 & -3.87 & 0.21 & -0.56 & -0.69 & -11.1 \\
\hline$R^{2}$ & 0.80 & 0.78 & 0.71 & 0.83 & 0.84 \\
\hline
\end{tabular}

${ }^{1} \mathrm{Len}=$ body length; $\mathrm{Xc}_{\mathrm{c}}=$ reactance; $\mathrm{Rs}=$ resistance; $\mathrm{Z}=$ impedance; voll $=(\text { distance between internal electrodes })^{2} / \mathrm{Rs} ;$ vol2 $=($ distance between internal electrodes $)^{2}: Z$.

ues observed in pigs (Swantek et al., 1992; Daza et al., 2006) or lambs (Altmann et al., 2005) compared with growing rabbits, probably due to differences in the volume of the animals.

The values of $\mathrm{CV}_{\mathrm{R}}$ were higher than those obtained in humans (between 0.3 and $2.8 \%$; Lukaski et al., 1985; Kushner and Schoeller, 1986; Deurenberg et al., 1988; Kushner, 1992) and could be explained by differences in the electrode application. In humans, electrodes are directly placed on the skin with a patch, whereas in rabbits, electrodes are applied with needles that go through the skin without puncturing the muscle, which could produce more variation in the BIA values.

\section{Body Composition}

The reason to express chemical composition on a DM basis is because water content varies with age, and this allows one to compare the variation of chemical composition with age without the effect of the differences in water content.

As was found in previous studies (Szendrö et al., 1998; Milisits et al., 2003), the body fat and energy content increased with the age of the animals. The maximum levels of water, protein, and ash coincide with the minimum values of fat and energy. It could be explained by differences in the growth pattern of the different body tissues with age due to allometric

Table 12. Regression coefficients and SD of the equations determined by partial least squares for predicting body chemical composition, expressed as grams $(n=150)$

\begin{tabular}{|c|c|c|c|c|c|}
\hline Independent variable $^{1}$ & Water, $g$ & Protein $\mathrm{g}$ & Ash, g & Fat, g & Energy, MJ \\
\hline Intercept & -15.5 & -35.7 & -8.61 & 56.8 & 1.96 \\
\hline Age & 1.15 & -0.090 & 0.21 & -1.76 & -0.0466 \\
\hline BW & 0.85 & 0.19 & 0.028 & -0.012 & $6.27 \cdot 10^{-4}$ \\
\hline $\mathrm{BW}^{2}$ & $-6.47 \cdot 10^{-5}$ & $1.09 / 10^{-5}$ & $-4.59 \cdot 10^{-7}$ & $5.51 / 10^{-5}$ & $2.68 \cdot 10^{-6}$ \\
\hline Len & -1.82 & 2.27 & 0.67 & -1.96 & 0.011 \\
\hline $\operatorname{Len}^{2}$ & -0.017 & -0.023 & -0.015 & 0.096 & $2.26 / 10^{-3}$ \\
\hline $\mathrm{Xo}$ & 1.29 & 3.49 & 0.68 & 0.19 & -0.11 \\
\hline Rs & -1.08 & -0.12 & -0.10 & 0.17 & -0.047 \\
\hline Z & 0.81 & -0.22 & -0.079 & -0.046 & -0.033 \\
\hline $\mathrm{Xe}^{2}$ & -0.90 & -0.069 & $-9.30<10^{-3}$ & $-8.60 \cdot 10^{-3}$ & $-5.032 \backslash 10^{-3}$ \\
\hline $\mathrm{Rs} \mathrm{s}^{2}$ & $1.38 / 10^{-3}$ & $5.11 \backslash 10^{-4}$ & $3.15 / 10^{-4}$ & $-2.23 \cdot 10^{-4}$ & $-6.83 \cdot 10^{-5}$ \\
\hline$z^{2}$ & $1.24 \cdot 10^{-3}$ & $4.14 \cdot 10^{-4}$ & $2.96 / 10^{-4}$ & $-2.28 / 10^{-4}$ & $-6.04 / 10^{-5}$ \\
\hline voll & 65.2 & -3.84 & 0.19 & -7.79 & -3.16 \\
\hline vol2 & -71.95 & 8.17 & -0.069 & 5.49 & 3.38 \\
\hline$R^{2}$ & 0.99 & 0.99 & 0.98 & 0.97 & 0.99 \\
\hline
\end{tabular}

${ }^{1}$ Len = body length; $X c=$ reactance; Rs = resistance; $Z=$ impedance; voll $=(\text { distance between internal electrodes })^{2}$;Rs; vol $2=($ distance between internal electrodes) $)^{2} / 2$. 
Table 13. Comparison of the prediction equations accuracy evaluated with independent data set $(n=50)$ by multiple linear regression (MLR) and partial least squares (PLS)

\begin{tabular}{|c|c|c|c|c|c|c|}
\hline \multirow[b]{2}{*}{ Item } & \multicolumn{3}{|c|}{$\mathrm{MLR}^{1}$} & \multicolumn{3}{|c|}{ PLS } \\
\hline & $R^{2}$ & MPE & $\overline{\text { RMPE } \%}$ & $R^{2}$ & MPE & $\overline{\mathrm{RMPE}, \%}$ \\
\hline \multicolumn{7}{|c|}{ Chemical body composition, \% DM } \\
\hline Water & 0.85 & 1.64 & 2.30 & 0.80 & 1.66 & 2.31 \\
\hline Protein & 0.79 & 2.82 & 5.04 & 0.78 & 2.89 & 5.17 \\
\hline Ash & 0.71 & 1.47 & 12.0 & 0.71 & 1.47 & 12.0 \\
\hline Fat & 0.83 & 4.45 & 18.9 & 0.83 & 4.39 & 18.6 \\
\hline Energy, kJ/10 & 0.86 & 70.2 & 3.19 & 0.84 & 77.4 & 3.52 \\
\hline \multicolumn{7}{|c|}{ Chenical body composition, $\mathbf{g}$} \\
\hline Water & 0.99 & 26.8 & 2.79 & 0.99 & 29.3 & 3.12 \\
\hline Protein & 0.99 & 13.4 & 6.15 & 0.99 & 11.0 & 5.13 \\
\hline Ash & 0.98 & 7.30 & 15.2 & 0.98 & 6.99 & 14.7 \\
\hline Fat & 0.97 & 26.7 & 24.3 & 0.97 & 28.0 & 25.5 \\
\hline Energy, MJ & 0.99 & 0.98 & 10.6 & 0.99 & 1.05 & 11.5 \\
\hline
\end{tabular}

${ }^{1} \mathrm{MPE}=$ mean prediction error; $\mathrm{RMPE}=$ relative mean prediction error.

growth (Cantier et al., 1969; Ouhayoun. 1984; Deltoro and Lopez, 1985). Between 25 and $35 \mathrm{~d}$ of age, more protein, a tissue associated with a higher level of water, and ash is deposited, whereas fat is deposited in a higher amount from this time onward. During this period, a decrease of fat content from 22.3 to 20.6 was detected, which can also be due to a reduction in milk intake, which contains a higher level of fat $(12.9 \%$; Maertens et al., 2010) than feed (3.3\% fat). Fat deposition increases from 20.6 to $36 \%$ from this time onward.

All parameters varied in following linear and quadratic trends, except protein, which evolved only linearly. This differs from results obtained by Szendrö et al. (1998), who found only a linear evolution of body composition with age (from 42 to $\mathrm{Il} 2 \mathrm{~d}$ ), without studying the quadratic evolution.

\section{Correlation between Variables and Detection of Multicollinearity}

Body fat and energy content were highly correlated with age, contrary to what was observed with protein, ash, and water. Other authors (Fraga et al., 1978, 1983; Pereda, 2010) found similar correlations of chemical composition with age in rabbits. Resistance values decrease with age, which could explain the negative correlation of this factor with fat and energy content (elements producing resistance to an electricity current flow) and the positive correlation with water, protein, and ash (conductors).

As expected, multicollinearity between Z, Rs, and $X_{c}$ was detected, as $Z$ is a linear combination of the other 2 parameters. The same was observed for voll and vol2. Multicollinearity between age, weight, and
Table 14. Comparison between analyzed and predicted chemical composition (mean [SD]) with multiple linear regression (MLR) and partial least squares (PLS) equations $(n=50)$ using a paired $t$ test

\begin{tabular}{|c|c|c|c|c|c|}
\hline Item & Analyzed & $\begin{array}{l}\text { Predicted } \\
\text { by MLR }\end{array}$ & $P$-value & $\begin{array}{c}\text { Predicted } \\
\text { by PLS }\end{array}$ & $P$-value \\
\hline \multicolumn{6}{|c|}{ Chemical composition. \% DM } \\
\hline Water, \% & $\begin{array}{l}71.6 \\
(3.05)\end{array}$ & $\begin{array}{l}71.0 \\
(2.46)\end{array}$ & 0.12 & $\begin{array}{l}71.1 \\
(2.34)\end{array}$ & 0.058 \\
\hline Protein & $\begin{array}{l}56.0 \\
(4.75)\end{array}$ & $\begin{array}{l}55.3 \\
(3.99)\end{array}$ & 0.12 & $\begin{array}{l}55.8 \\
(3.68)\end{array}$ & 0.72 \\
\hline Ast & $\begin{array}{l}12.2 \\
(1.44)\end{array}$ & $\begin{array}{l}11.3 \\
(0.72)\end{array}$ & $<0.0001$ & $\begin{array}{l}11.3 \\
(0.83)\end{array}$ & 0.0074 \\
\hline Fat & $\begin{array}{l}23.5 \\
(6.20)\end{array}$ & $\begin{array}{l}26.3 \\
(4.38)\end{array}$ & $<0.0001$ & $\begin{array}{l}25.3 \\
(4.93)\end{array}$ & $<0,0001$ \\
\hline $\begin{array}{l}\text { Energy, kJ } 100 \\
\text { g DM }\end{array}$ & $\begin{array}{l}2,200 \\
(124)\end{array}$ & $\begin{array}{l}2,230 \\
(95.6)\end{array}$ & 0.0018 & $\begin{array}{l}2,234 \\
(121)\end{array}$ & 0.0007 \\
\hline \multicolumn{6}{|c|}{ Chemical composition, g } \\
\hline Water & $\begin{array}{l}960 \\
(490)\end{array}$ & $\begin{array}{c}980 \\
(503)\end{array}$ & 0.94 & $\begin{array}{c}943 \\
(494)\end{array}$ & 0.57 \\
\hline Protein & $\begin{array}{l}218 \\
(124)\end{array}$ & $\begin{array}{c}223 \\
(125)\end{array}$ & 0.94 & $\begin{array}{c}214 \\
(124)\end{array}$ & 0.43 \\
\hline Ash & $\begin{array}{c}48.0 \\
(27.5)\end{array}$ & $\begin{array}{l}45.3 \\
(24.4)\end{array}$ & 0.067 & $\begin{array}{c}44.2 \\
(24.9)\end{array}$ & 0.018 \\
\hline Fat & $\begin{array}{l}110 \\
(90.3)\end{array}$ & $\begin{array}{l}123 \\
(97.0)\end{array}$ & 0.0009 & $\begin{array}{l}112 \\
(92.4)\end{array}$ & 0.0009 \\
\hline Energy, $\mathrm{MJ}$ & $\begin{array}{c}9.24 \\
(6.22)\end{array}$ & $\begin{array}{c}9.61 \\
(6.56)\end{array}$ & 0.89 & $\begin{array}{c}9.13 \\
(6.40)\end{array}$ & 0.97 \\
\hline
\end{tabular}

animal length was also found, because of the parallel evolution of these parameters with time

\section{Validation of Prediction Equations}

In case of multicollinearity, PLS regression models are usually more accurate than MLR models. However, the results of this study, as also was observed by Pereda (2010), showed that MLR equations, despite multicollinearity, were more robust, because their RMPE were similar to or lower than PLS equation error values. Therefore, because the number of independent variables included in MLR equations was lower than in PLS equations, the use of MLR equations for estimating chemical whole body composition of growing rabbits is advised.

Bioelectrical impedance analysis measurements overestimate fat and energy body content (around 11.9 and $1.4 \%$, respectively) and underestimate ash content (7\%). Those differences between analyzed and predicted body composition for ash (\% DM and g), fat (\% DM and $\mathrm{g}$ ), and energy ( $\mathrm{kJ} / 100 \mathrm{~g} \mathrm{DM}$ ) could be due to the higher variability observed for analyzed values than for predicted values for these variables, whereas for protein and water, this variability was lower. On the other hand, these parameters also had the highest RMPE values, which could explain these results. The RMPE values of the equations, expressed in percent DM, were lower 

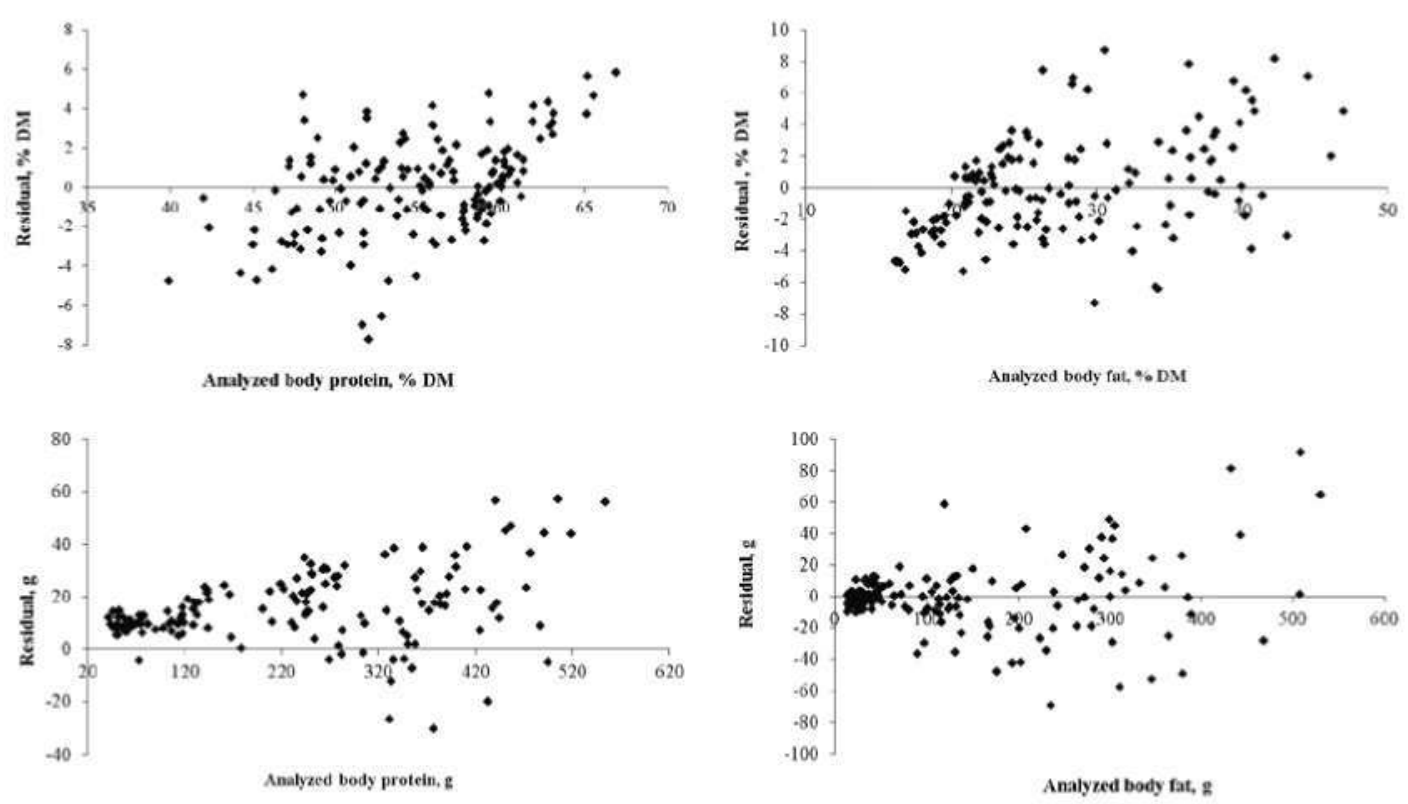

Figure 2. Residuals distribution of multiple linear regression equations for body protein and energy content expressed as a percentage and as grams (calibration group; $n=150$ ).

than those expressed in grams, indicating a higher precision of the first equations, despite the higher $R^{2}$ values of the second ones, which could be explained by the higher variance interval of the values expressed in grams related to those expressed as a percentage.

As was observed in the residual distribution, MLR equations showed a slight overestimation of body protein content of rabbits with the lowest protein content and underestimate it in rabbits with the highest values. Also, fat slightly overestimates the carcass fat in rabbits with the lowest body fat content. Residuals are more homogenous when chemical composition was expressed as a percentage because the range is reduced in comparison with when it was expressed as grams.

Comparing these results with the results obtained by other authors who used other in vivo techniques, it was detected than none of them showed the RMPE values. Milisits et al. (2000) obtained a maximum value of $R^{2}$ of 0.29 when fat content of animals, included gastrointestinal content, was predicted by the TOBEC method. Fekete and Brown (1993), used both the TOBEC and the deuterium dioxide methods to estimate empty body fat. In the case of the TOBEC method, authors observed an $R^{2}$ value of 0.97 in animals that did not receive any food or water before slaughter. When the deuterium oxide method was tested in animals fed ad libitum, the value of $R^{2}$ was 0.71 . In another study, Köver et al. (1998) obtained an $r$ value of $0.39\left(R^{2}=0.15\right)$ using a magnetic resonance imaging method in animals at $12 \mathrm{wk}$ of age. The same authors reported higher $R^{2}$ values of 0.59 to 0.89 in animals 16 wk old. In all those studies, the values of $R^{2}$ were similar to or lower than the value found in our work $(0.97)$, so the adjustment of the equations obtained in this study using BIA is comparable to other methods. However, some advantages can be added to BIA, such as its accuracy and robustness, relatively low cost of the device, no preparation of the animals needed, and easy learning and application of this method.

According to Petracci and Cavani (2013), rabbit meat has high potential to meet consumers' demands for food health and industry requirements. Nutritional and technological properties of rabbit meat have been widely investigated in recent years (Dalle Zotte, 2002; Pla et al., 2004; Dalle Zotte et al., 2016). For this purpose, the use of BIA as an in vivo method can be interesting to determine body composition without the need to slaughter animals.

\section{LITERATURE CITED}

Akaike, H. 1969. Fitting autoregressive models for prediction. Ann. Inst. Stat. Math. 21:243-247. doi:10.1007/BF02532251

Altmann, M., U. Pliquett, R. Suess, and E. Von Borell. 2005. Prediction of carcass composition by impedance spectroscopy in lambs of similar weight. Meat Sci. 70:319-327. doi:10.1016/j. meatsci.2005.01.018

Amemiya, T. 1985. Advanced econometrics. 1st ed., Harvard Univ. Press, Cambridge, UK.

AOAC. 2000. Official methods of analysis.17th ed. AOAC Int., Washington, DC.

Berg, E. P., and M. J. Marchello. 1994. Bioelectrical impedance analysis for the prediction of fat-free mass in lambs and lamb carcasses. J. Anim. Sci. 72:322-329.

Cantier, J., A. Vezinhet, R. Rouvier, and L. Dauzier. 1969. Allométrie de croissance chez le lapin (Oryctolagus cuniculus). (In French.) Ann. Biol. Anim. Biochim. Biophys. 9:5-39. doi:10.1051/ md: 19690101

Dalle Zotte, A. 2002. Perception of rabbit meat quality and major factors influencing the rabbit carcass and meat quality. Livest. Prod. Sci. 75:11-32. doi:10.1016/S0301-6226(01)00308-6 
Dalle Zotte, A., M. Cullere, H. Rémignon, L. Alberghiui, and G. Paci. 2016. Meat plysical quality and muscle fibre properties of rabbit meat as affected by the sire breed, season, parity order and gender in an organic production system. World Rabbit Sci. 24:145-154. doi: 10.4995/wrs. 2016.4300

Daza, A., A. Mateos, I. Ovejero, and C. J. López Bote. 2006. Prediction of body composition in Iberian pig by means of bioelectrical impedance. Meat Sci. 72:43-46, doi:10,1016/j.meatsci. $2005,05.026$

de Blas, C., and G. G. Mateos. 2010. Feed formulation. In: C. de Blas and J. Wiseman, editors, Nutrition of the rabbit. CABI Publ., CAB Int, Wallingford, UK. p. 222-232. doi: $10.1079 / 9781845936693.0222$

Deltoro, J., and A. M. Lopez. 1985. Allometric changes during growth in rabbits. J. Agric. Sci. 105:339-346. doi:10.1017/ SOO21859600056392

Deurenberg, P., J. A. Weststrate, I. Paymans, and K. Van der Kooy. 1988. Factors affecting bioelectrical impedance measurements for assessing body composition. J. Clin. Nutr. 42:1017-1022.

Fekete S., and D. L. Brown. 1992. Prediction of body composition in rabbits by deuterium oxide dilution and total body electrical conductivity with validation by direct chemical analysis. J. Appl. Rabbit Res. 15:787-798.

Fekete, S., and D. L. Brown. 1993. The major chemical components of the rabbit whole body measured by direct chemical analysis, deuterium oxide dilution and total body electrical conductivity. J. Vet. Nutr. 2:23-29.

Fortun-Lamothe, L., F. Lebas, B. Lamboley-Gaüzére, and C. Bannelier. 2002. Prediction of body composition in rabbit females using total body electrical conductivity (TOBEC). Livest. Prod. Sci. 78:133-142. doi: 10.1016/S0301-6226(02)00087-8

Fraga, M. J., J. C. de Blas, E. Pérez, J. M. Rodríguez, C. J. Pérez, and J. F. Gálvez. 1983. Effect of diet on chemical composition of rabbits slaughtered at fixed body weights. J. Anim. Sci. 56:1097-1104. doi: 10.2527/jas1983.5651097x

Fraga, M. J., A. Torres, E. Pérez, J. F. Gálvez, and J. C. de Blas. 1978. Body composition in suckling rabbits. J. Anim. Sci. 47:166-175. doi: $10.2527 /$ jas $1978.471166 \mathrm{x}$

Government of Spain. 1999. Real Decreto 609/1999, de 16 de abril, por el que se modifica el Real Decreto 2257/1994, de 25 de noviembre, por el que se aprueban los métodos oficiales de análisis de piensos o alimentos para animales y sus primeras materias. BOE-A-1999-9657. (In Spanish.) Madrid, Spain.

Government of Spain. 2013. Real Decreto 53/2013, de 1 de febrero, por el que se establecen las normas básicas aplicables para la protección de los animales utilizados en experimentación y otros fines científicos, incluyendo la docencia. BOE-A-2013-1337. (In Spanish.), Madrid, Spain.

Hocking, R. R. 1976. The analysis and selection of variables in linear regression. Biometrics 32:1-49. doi: $10.2307 / 2529336$

International Organization for Standardization (ISO). 1997. Method 1442:1997. Meat and meat products - Determination of moisture content (reference method). ISO, Geneva, Switzerland.

Judge, G. G., W. E. Griffiths, R. C. Hill, and T. Lee. 1980. The theory and practice of econometrics. Ist ed. Joln Wiley \& Sons Canada, Limited, New York, NY.

Köver, G. I., P. Sorensen, Z. S. Szendrö, and G. Milisits. 1996. In vivo measurement of perirenal fat by magnetic tomograply. In: Proc. 6th World Rabbit Congr., Toulouse, France. p. 191-194.

Köver, G., Z. Szendrô, R. Romvari, J. F. Jensen, P. Sorensen, and G. Milisits. 1998 . In vivo measurement of body parts and fat deposition in rabbit by MRI. World Rabbit Sci. 6:231-234.
Kushner, R. F. 1992. Bioelectrical impedance analysis: A review of principles and applications. Am. J. Clin. Nutr. 11:199-209.

Kushner, R. F, and D. A. Schoeller. 1986. Estimation of total body water in bioelectrical impedance analysis. Am. J. Clin. Nutr 44:417-424.

Lukaski, H. C., W. W. Bolonchuck, C. B. Hall, and W. A. Siders. 1985. Validation of tetrapolar bioelectrical impedance method to assess human body composition. J. Appl. Physiol. 60:1327-1332.

Maertens, L., F. Lebas, and Z. S. Szendro. 2010. Rabbit milk: A review of quantity, quality and non-dietary affecting factors. World Rabbit Sci. 14(4):205-230. doi: $10.4995 /$ wrs. 2006.565

Mallows, C. L. 1973. Some comments on Cp. Teclnometrics 15:661675 .

Milisits, G., T. Gyamati, and Z. S. Szendrö. 1999. In vivo estimation of body fat of new-bom rabbits using the TOBEC method. World Rabbit Sci. 7(3):151-154.

Milisits, G., A. Lévai, G. Andrássy-Baka, and R. Romvári. 2003. In vivo examuination of fat deposition in growing rabbits selected for ligh and low body fat content. Agric. Conspectus Scintificus 68(3): 145-149.

Milisits, G., Z. Szendrö, G. Milálovics, E. Biró-Németh, I. Radna, and $A$. Lévai. 2000. Use of the TOBEC method for predicting the body composition of growing rabbits. In: 7th World Rabbit Congr., Valencia, Spain. p. $637-642$.

Nicodemus, N., N. Pereda, C. Romero, and P. G. Rebollar. 2009 Évaluation de la technique d'impedance bioélectrique (IBE) pour estimer la composition corporelle de lapines reproductives. (In French.) In: Proc. 13th J. Rech. Cunicole, Paris, France. p $109-112$.

Ouhayoun, J. 1984. La croissance et le developpement du lapin de chair. (In French.) Cuni Sci. 1:1-5.

Pereda, N. 2010. Evaluación de la técnica del análisis de impedancia bioeléctrica para predecir la composición corporal: Aplicación en conejas sometidas a diferentes sistemas de alimentación durante la recria. (In Spanish.) PlD Thesis, Universidad Politécnica de Madrid, Spain.

Petracci, M., and C. Cavani. 2013. Rabbit meat processing: Historical perspective to future directions. World Rabbit Sci. 21:217-222. doi: $10.4995 /$ wrs. 2013.1329

Pla, M, M. Pascual, and B. Ariño. 2004. Protein, Fat and moisture content of retail cuts of rabbit meat evaluated with the NIRS methods. World Rabbit Sci. 12:149-158.

Swantek, P. M., J. D. Crenshaw, M. I. Marchello, and H. C. Lukaski. 1992. Bioelectrical impedance: A non-destructive method to determine fat-free mass of live market swine and pork carcasses. J. Anim. Sci. 70:169-177. doi: 10.2527/1992.701169x

Swantek, P. M., M. J. Marchello, J. E. Tilton, and J. D. Crenshaw. 1999 Prediction of fat-free mass pigs from 50 to 130 kilograms live weight. J. Anim. Sci. 77:893-897. doi: 10.2527/1999.774893x

Szendro, Z. S., P. Horn, G. I. Kover, E. Berényl, I. Radnai, and E. Biro-Nemeth. 1992. In vivo measurement of the carcass traits of meat type rabbits by X-ray computerised tomography. J. Appl. Rabbit Res. 15:799-809.

Szendrö, Z. S., A. Kenessey, J. F. Jensen, N. E. Jensen, J. Csapó, R. Romvari, and G. Milisits. 1998. Effect of genotype, age, body weight and sex on the body composition of growing rabbits. Work Rabbit Sci. 6(3-4):277-284.

Talma, H., M. I. Clinapaw, B. Bakker, R. A. HiraSing, C. B. Terwee, and T. M. Altenburg. 2013. Bioelectrical impedance analysis to estimate body composition in children and adolescents: A systematic review and evidence appraisal of validity, responsiveness, reliability and measurement error. Obes. Rev. 14:895-905. 